\title{
Congenital absence of insulin cells in a neonate with diabetes mellitus and mutase-deficient methylmalonic acidaemia
}

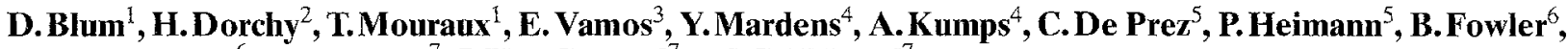 \\ R. Baumgartner ${ }^{6}$, L. Bouwens $^{7}$, J. Van Gompel ${ }^{7}$ and G. Klöppel ${ }^{7}$ \\ ${ }^{1}$ Neonatal Clinic, Hôpital Universitaire des Enfants Reine Fabiola, Université Libre de Bruxelles (ULB) \\ ${ }^{2}$ Diabetes Clinic, Hôpital Universitaire des Enfants Reine Fabiola, Université Libre de Bruxelles (ULB) \\ ${ }^{3}$ Genetics Clinic, Hôpital Universitaire des Enfants Reine Fabiola, Université Libre de Bruxelles (ULB) \\ ${ }^{4}$ Laboratory of Medical Biochemistry, Institute of Pharmacy, Université Libre de Bruxelles (ULB) \\ ${ }^{5}$ Department of Anatomic Pathology, Hopital Brugmann, Brussels, Belgium \\ ${ }^{6}$ Metabolic Unit, Children's Hospital, Basel, Switzerland \\ ${ }^{7}$ Department of Experimental Pathology, Vrije Universiteit Brussel, Campus Jette, Brussels, Belgium
}

\begin{abstract}
Summary. We report on a female neonate with diabetes mellitus and methylmalonic acidaemia, who died at age 16 days. Using immunocytochemistry, electron microscopy and in situ hybridisation, we were unable to demonstrate any insulin cells in the pancreatic islets. Methylmalonic acidaemia was caused by a methylmalonyl coenzyme A mutase apoenzyme defect. The metabolic crisis of the methylmalonic acidaemia
\end{abstract}

aggravated the diabetes and may explain the failure of insulin therapy. Our results suggest that the infant suffered from a congenital absence of beta cells associated with a genetically transmitted mutase apoenzyme defect.

Key words: Congenital diabetes mellitus, absence of beta cells, methylmalonic acidaemia, mutase deficiency.
Neonatal diabetes mellitus, whether transient or permanent, is rare. The transient form, attributed to a delay in beta-cell maturation, occurs in small for gestational age infants usually before the third week of life. Blood glucose levels are very high, but ketonuria is mild or absent. These infants are insulin-dependent for a short time (usually less than 3 months), but then slowly recover and eventually become normoglycaemic. The permanent form at the start is clinically indistinguishable from the transient form, but evolves into irreversible diabetes [1-11]. Its pathogenesis is unknown, but rare causes such as aplasia of the pancreas [12-18] or congenital absence of the islets of Langerhans $[19,20]$ have been reported.

Recently, Wong et al. [21] reported an isolated absence of beta cells in a diabetic neonate who died at the age of 3 days. We report here on another diabetic neonate with congenital absence of beta cells demonstrated by immunocytochemistry, electron microscopy and in situ hybridization. In addition, this patient had methylmalonic acidaemia due to methylmalonic CoA mutase deficiency.

\section{Case report}

Patient L.G., a Caucasian female neonate, was the first child of a healthy non-consanguineous 32-year-old woman. She was born small for gestational age in the 40th week of gestation: the birth weight was $1950 \mathrm{~g}$, length $44 \mathrm{~cm}$ and head circumference $34 \mathrm{~cm}$. Apgar score was 9/10. Fetal growth had been considered normal by the at- tending obstetrician. Pregnancy and birth were uneventful. Serologic tests indicated previous exposure of the mother to cytomegalic virus, rubella and toxoplasmosis. Both parents had a family history of Type 2 (non-insulindependent) diabetes mellitus among their first-degree relatives. The infant was brought to medical attention at $28 \mathrm{~h}$ of life because blood glucose showed high values $(20.0 \mathrm{mmol} / \mathrm{l})$ on routine measurement. Glycosuria and ketonuria (Acetest) were also present. At $48 \mathrm{~h}$ of life the baby was transferred to the neonatal intensive care unit of the University Children's Hospital Queen Fabiola in Brussels with the diagnosis of neonatal diabetes mellitus. On admission, the child was found to be pale, hypothermic $\left(35.7^{\circ} \mathrm{C}\right)$, dehydrated (weight loss: $14 \%$ of body weight at birth), tachypneic and markedly hypotonic. There was little subcutaneous tissue. A grade II systolic murmur was heard. The liver was felt at $1 \mathrm{~cm}$ below the right costal margin. The initial laboratory tests disclosed a blood glucose of $20.7 \mathrm{mmol} / \mathrm{l}$ with massive glycosuria and mild ketonuria, as well as a mild compensated metabolic acidosis (arterial pH 7.39; base excess $-7 \mathrm{mmol} / \mathrm{l}$; bicarbonate $15 \mathrm{mmol} / \mathrm{l} ; \mathrm{pCO}_{2} 25 \mathrm{~mm} \mathrm{Hg}[3.33 \mathrm{kPa}]$, blood lactate $4.56 \mathrm{~mol} / 1$ [normal range 0 to 1.80 ], pyruvate $0.25 \mathrm{~mol} / 1$ [normal range 0.06 to 0.12 ]). On day 3 plasma ammonia concentration was $463 \mu \mathrm{mol} / 1$ (normal range $30-60$ $\mu \mathrm{mol} / \mathrm{l})$ with elevated blood urea $(6.7 \mathrm{~mol} / 1)$. It was thought that hyperammonaemia was due to intense catabolism and insufficient caloric supply during the infant's first 3 days. Lipids and glucose were administered intravenously and the amount of protein was reduced to 
Table 1. Methyl malonyl CoA mutase activity and ${ }^{14} \mathrm{C}$-propionate incorporation in cultured fibroblasts from the patient and an agematched control subject

\begin{tabular}{lccl}
\hline \multicolumn{4}{l}{ Methyl malonyl CoA mutase activity } \\
\hline $\begin{array}{l}\text { Ado-Cbl } \\
\mathrm{mol} / 1\end{array}$ & \multicolumn{2}{l}{ Succinate formed $\left(\mathrm{pmol} \cdot \mathrm{min}^{-1} \cdot \mathrm{mg}^{\text {protein }}{ }^{-1}\right)$} \\
\cline { 2 - 4 } & Patient & Control & $\begin{array}{l}\text { Reference values } \\
(\text { mean } \pm \mathrm{SD})\end{array}$ \\
\hline 0 & & 157 & $273 \pm 64$ \\
$5 \times 10^{-5}$ & 6.4 & 392 & $642 \pm 130$ \\
\hline
\end{tabular}

Ado-Cbl, Adenosylcobalamin

${ }^{14} \mathrm{C}$-propionate incorporation

\begin{tabular}{llcl}
\hline $\mathrm{OH}-\mathrm{Cbl}$ & \multicolumn{3}{l}{${ }^{{ }^{4} \mathrm{C} \text { propionate fixation }\left(\mathrm{pmol} \cdot \mathrm{mg} \text { protein }^{-1} \cdot 16 \mathrm{~h}^{-1}\right)}$} \\
\cline { 2 - 4 }$\mu \mathrm{g} / \mathrm{l}$ & Patient & Control & $\begin{array}{l}\text { Reference values } \\
(\text { mean } \pm \mathrm{SD})\end{array}$ \\
\hline 0 & 642 & 9596 & $8315 \pm 4935$ \\
1.0 & 605 & 10010 & $8166 \pm 3830$ \\
\hline
\end{tabular}

$\mathrm{OH}-\mathrm{Cbl}$, Hydroxycobalamin

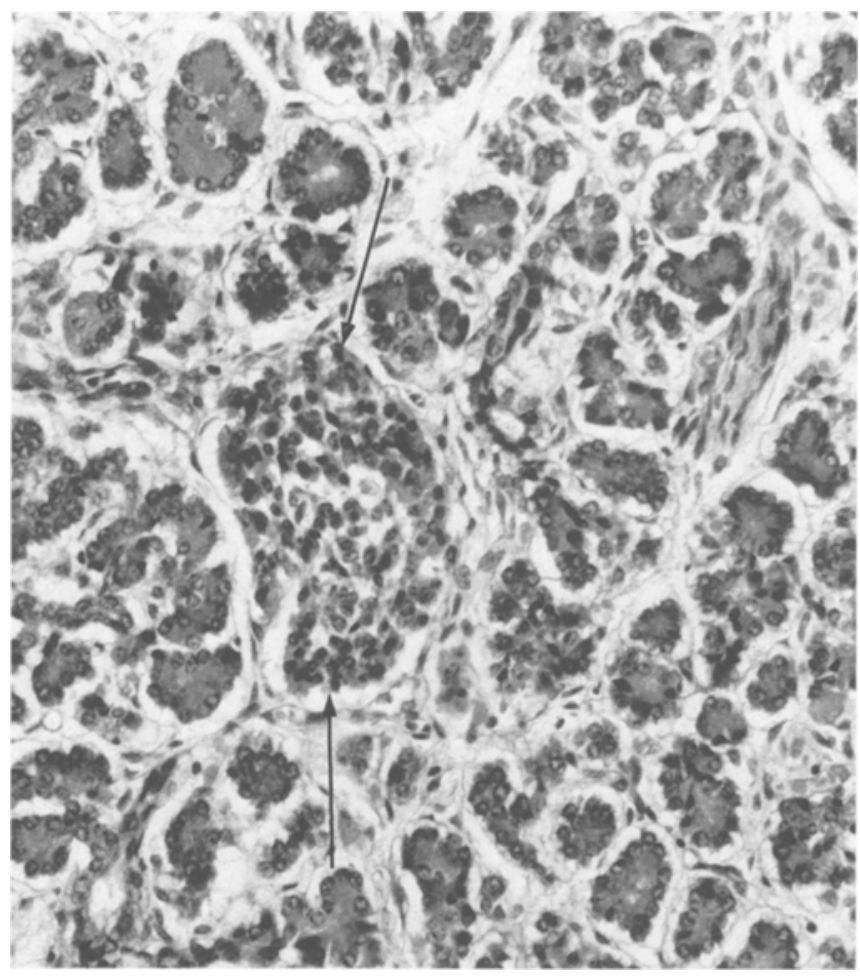

Fig. 1. Section from the patient's pancreas showing an apparently normal islet (arrows). Haematoxylin and eosin stain (magnification $\times 125)$

$0.5 \mathrm{~g} / \mathrm{kg}$. Insulin was infused using a pump at a rate of $0.1 \mathrm{IU} \cdot \mathrm{kg}^{-1}$. body weight $\mathrm{h}^{-1}$. As a result of these combined measures a rapid decrease in ammonaemia was observed. After 1 day of insulin treatment the blood glucose level transiently returned to normal range but was poorly controlled thereafter with values up to $46 \mathrm{mmol} / \mathrm{l}$ on day 6 despite an increase in the insulin dose to $0.8 \mathrm{IU}$. $\mathrm{kg}^{-1}$. body weight $\mathrm{h}^{-1}$. Albumin was added to the insulin solution to avoid adsorption of the hormone to the tubes of the pump. On day 7 blood glucose decreased, fluctuating between 3.3 and $14 \mathrm{mmol} / \mathrm{l}$, and ketonuria disap- peared. The insulin doses could be reduced to 0.1 to $0.3 \mathrm{IU} \cdot \mathrm{kg}^{-1}$. body weight $\mathrm{h}^{-1}$. Further diagnostic workup concerning the diabetes included ultrasonography which demonstrated a normal pancreas, and no detectable C-peptide or insulin at day 3 . The absence of serum C-peptide was confirmed on day 7 when the child received exogenous insulin. There was no evidence of autoantibodies to islet cells (ICA) or insulin (IAA). HLA DQ genotype was $A_{3} B_{3.1} / A_{3} B_{3.1}$, which is not associated with a genetic susceptibility to Type 1 (insulin-dependent) diabetes. Antibodies against Coxsackie $\mathrm{B} 1$ to $\mathrm{B} 6$ viruses were present in the serum: Coxsackie $B_{1}: 1 / 128 ; B_{2}: 1 / 64$; $\mathrm{B}_{3}: 1 / 128 ; \mathrm{B}_{4}: 1 / 64 ; \mathrm{B}_{5}: 1 / 128 ; \mathrm{B}_{6}: 1 / 64$. From day 4 plasma $\mathrm{pH}$ fell reaching a value of 7.12 on day 7 despite the addition of sodium bicarbonate to the treatment. Base excess fluctuated between -5 and $-12 \mathrm{mmol} / \mathrm{l}$, anion gap between 13 and $34 \mathrm{mmol} / \mathrm{l}$. Clinical deterioration soon occurred in the form of seizures, loss of normal reflex activity including apnoea requiring ventilatory support on day 8 . At that time the liver was enlarged $(3 \mathrm{~cm}$ below the right costal margin). Because of persisting acidosis after stabilization of glycaemia, an inborn error of metabolism was suspected. Metabolic tests disclosed increased plasma lactate $(9 \mathrm{mmol} / \mathrm{l})$, pyruvate $(0.25 \mathrm{mmol} / \mathrm{l})$, ammonia (114 to $563 \mu \mathrm{mol} / \mathrm{l}$ ), plasma and urinary glycine. Plasma carnitine was low (total $19 \mu \mathrm{mol} / 1$, free $<3 \mu \mathrm{mol} / 1$; normal range 30 to $65 \mu \mathrm{mol} / 1$ and 21 to $55 \mu \mathrm{mol} / 1$, respectively). In conjunction with a pancytopoenia detected in the peripheral blood and bone marrow, these data suggested an organic aciduria, especially of the propionic or methylmalonic acidaemia type. The latter diagnosis was confirmed through GC-MS analysis of urinary organic acids, revealing grossly elevated $(62.5 \mu \mathrm{mol} / \mathrm{g}$ creatinine $)$ methylmalonic acid. In addition to insulin, the patient was then treated with $\mathrm{L}$-carnitine $100 \mathrm{mg} \cdot \mathrm{kg}^{-1}$. day ${ }^{-1}$ from day 6 and with supplements of vitamin $\mathrm{B} 12$ (OH cobalamin) from day 13 . As death occurred at day 16 , the therapeutic response to vitamin B12 could not be assessed. The electroencephalogram, normal on day 2 , showed evidence of cerebral dysfunction on day 9. Brain-stem-evoked potentials were abnormal. An open ductus arteriosus with cardiac failure required treatment with indomethacin and digoxin from day 7 . On day 9 a necrotizing enterocolitis was diagnosed; enteral feeding was interrupted and appropriate antibiotics were given. As the disease progressed, the child became totally unresponsive and died 1 week later (day 16). Cultured fibroblast studies showed undetectable methylmalonyl coenzyme A mutase activity with and without adenosylcobalamin (Table 1) and decreased ${ }^{14}$ C-propionate uptake unresponsive to hydroxycobalamin (Table 1 ). These data are consistent with a mutation in the methylmalonyl coenzyme A mutase gene of the mut ${ }^{0}$ type.

\section{Pathological findings}

At autopsy, which was performed $2 \mathrm{~h}$ after death, the pancreas showed no macroscopic changes. Histologically, the lobular architecture was well preserved. Scattered among acinar cells and occasionally within interstitial septa there were apparently normal islets of Langerhans (Fig. 1). Peri- 

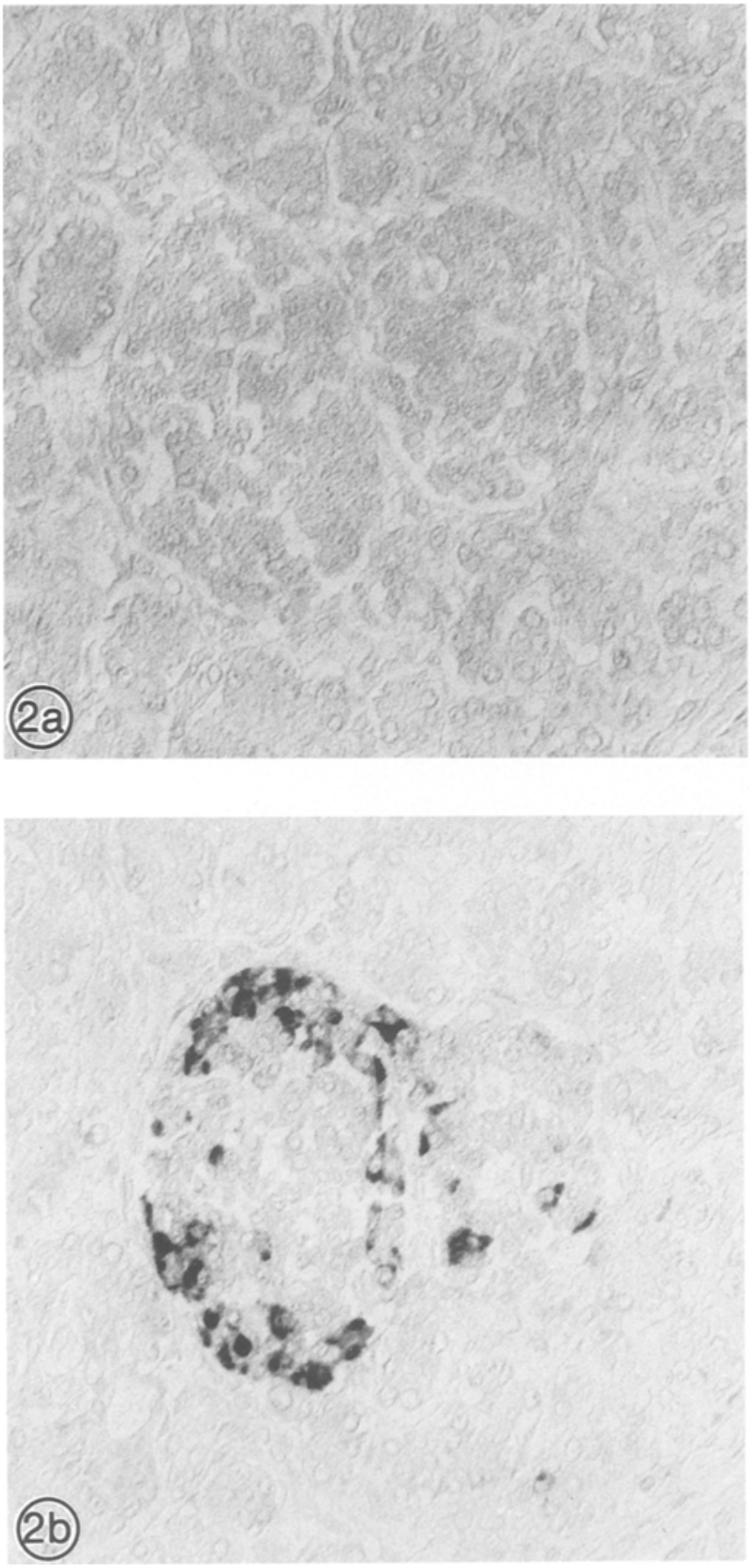

Fig. 2a-d. Immunostaining for insulin (a), glucagon (b), somatostatin (c) and synaptophysin (d) in consecutive sections demonstrates the absence of immunoreactive insulin from the islet cells, whereas

insular or interstitial infiltrates of lymphocytes or other haematopoietic cells were lacking [22].

Immunocytochemical staining (avidin-biotin-peroxidase complex technique) of the islets with the neuroendocrine marker synaptophysin (polyclonal rabbit antibody; gift of Dr. R. Jahn, München, FRG; dilution 1:2000) revealed islets of Langerhans which did not differ in distribution or in size from those of age-matched control subjects. Differential immunostaining for the four pancreatic
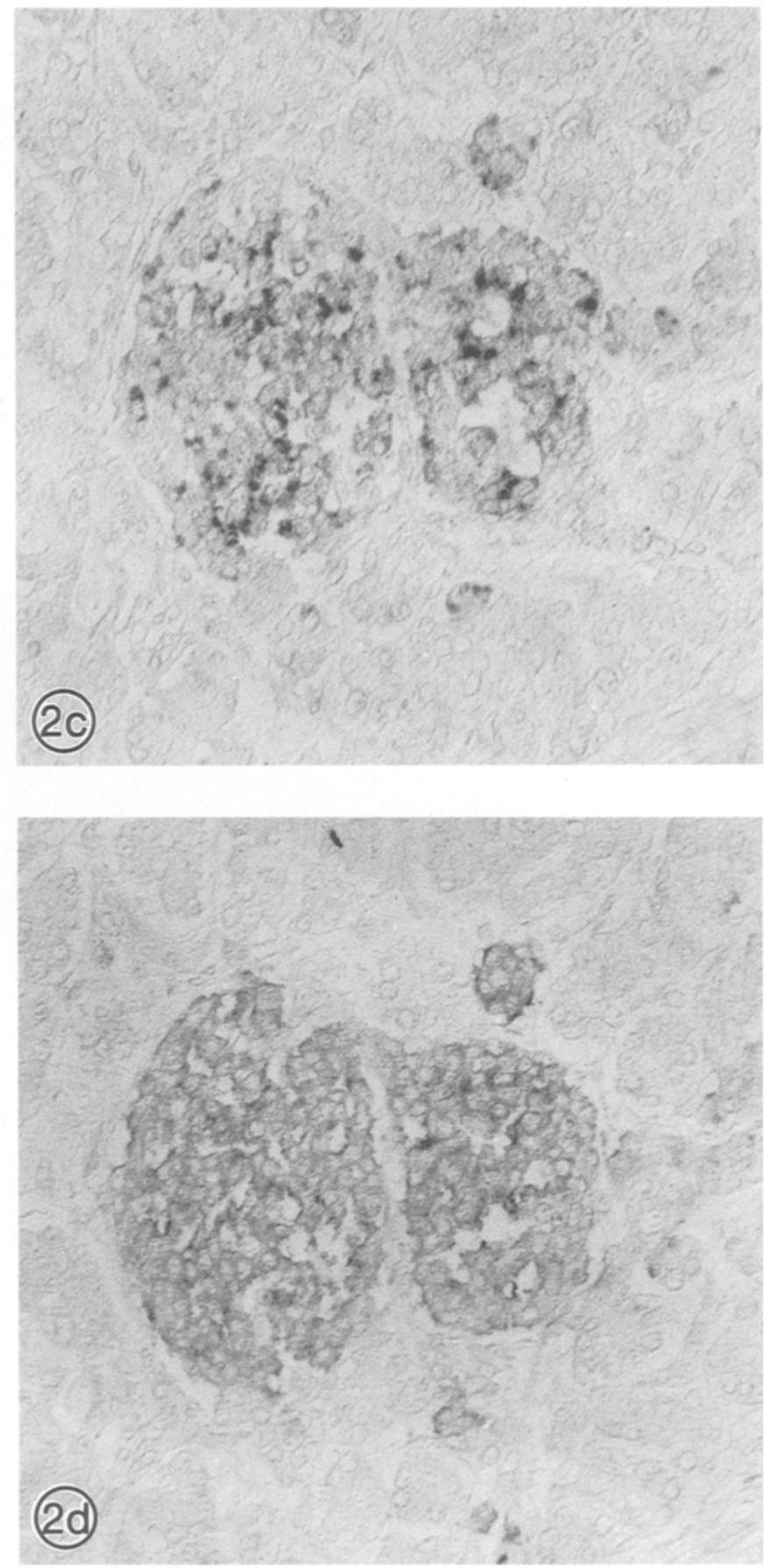

glucagon and somatostatin-positive cells are present (magnification $\times 440$ )

hormones identified cells positive for glucagon (polyclonal rabbit antiserum, Milab, Malmö, Sweden; dilution 1:2500), somatostatin (polyclonal rabbit antiserum, Immunonuclear, Stillwater, Mich., USA; dilution 1:2000) and pancreatic polypeptide (PP) (polyclonal rabbit antiserum; gift of Dr. R. E. Chance, Indianapolis, Ind., USA; dilution 1:10000), but not for insulin (monoclonal mouse antibody; Biogenex, Dublin, Calif., USA; dilution 1:5000) (Fig. 2a-c) or amylin (islet amyloid polypeptide, IAPP; 




Fig.3. Portion of an islet showing well-granulated islet cells with secretory granules characterizing glucagon cells (A) and somatostatin cells (D). (magnification $\times 5500$ )



Fig. 4a,b. In situ bybridization for insulin using ${ }^{35}$ S-labelled oligonucleotide probes against rat preproinsulin: (a) absence of signals over an islet of the patient (arrows); (b) demonstration of signals

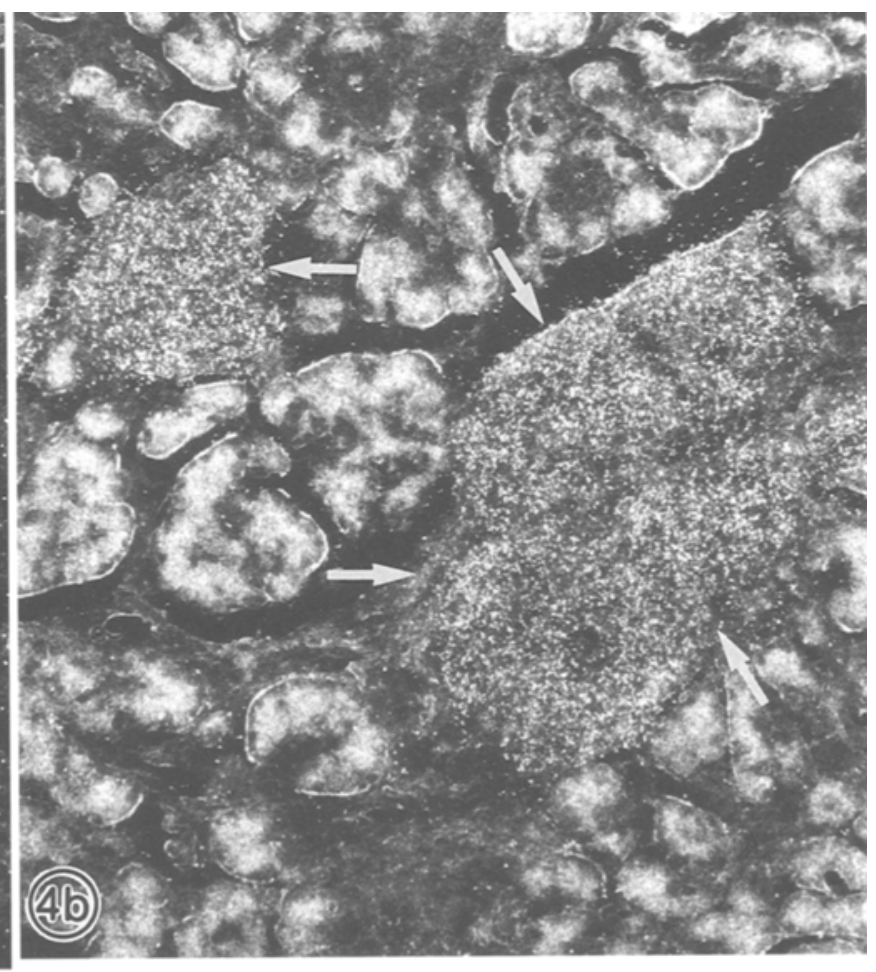

over the islet (arrows) of a pancreas from a non-diabetic newborn. There is unspecific illumination of the acinar cells surrounding the islets in b. (dark-field photography, magnification $\times 125$ )

tatin cells were second in frequency to PP-cells. All cells in the islets stained with synaptophysin (gift of Dr. R. Jahn, Planegg-Martinsried, FRG, dilution 1:4000) (Fig. 2d).

The ultrastructural aspects of the islets (fixation of post-mortem tissue in $2 \%$ glutaraldehyde; post-fixation in $1 \% \mathrm{OsO}_{4}$; embedded in Epon 812 ) corresponded to the immunocytochemical pattern. All cells were well-granulated and contained secretory granules, either typical for were somatostatin-positive cells. In the PP-rich islets of the posterior part of the head of the pancreas, somatos-

gift of Dr. O.Madsen, Gentofte, Denmark; dilution (not shown). Because of the lack of insulin cells the relative proportion of the non-insulin cells was increased, while their spatial distribution remained about the same. In the PP-poor islets of the tail of the pancreas, $30-40 \%$ of the cells were glucagon-positive and $60-70 \%$ 
glucagon cells, somatostatin cells or PP cells. We found no cells with typical beta granules (Fig. 3).

In situ hybridization for insulin using oligonucleotide probes against mRNA of rat preproinsulin which were found to cross-hybridize with mRNA of human proinsulin, failed to reveal any specific signal in the pancreas and particularly over the islets (Fig. 4a). In situ hybridization of two control pancreata from non-diabetic newborns (post-mortem examination within 4 to $6 \mathrm{~h}$ after death) resulted in a positive signal over the islets (Fig. 4 b).

\section{Discussion}

We studied the pancreas of a diabetic neonate with methylmalonic acidaemia, using immunocytochemistry, electron microscopy and in situ hybridization, and found a complete absence of islet cells expressing insulin at the mRNA or protein level. The lack of any sign of recent beta-cell necrosis (such as dense inflammatory infiltrations or necrotic islet cells) in the pancreas of this neonate whose diabetes was diagnosed within $28 \mathrm{~h}$ after birth, suggests a congenital absence of beta cells and argues against a post-natal destruction of beta cells. To our knowledge this is the second patient with a congenital beta-cell absence and the first with an associated mutase-deficient methylmalonic acidaemia.

Non-transitory neonatal diabetes diagnosed during the first month of life is extremely rare. So far 31 well-documented cases have been published. The cause of this permanent neonatal diabetes form is unknown in 21 cases [111; cases published before 1975 are reviewed in 1]. Aplasia of the pancreas, which is usually associated with other malformations such as gall-bladder agenesis, accounts for eight cases [12-18]. Congenital absence of the islets of Langerhans was thought to be the cause in two other neonates with diabetes, but the histological findings were not substantiated by immunocytochemistry or electron microscopy $[19,20]$. In the two cases published by Ivarsson et al. [11] a non-islet pancreatic autoantibody was demonstrated, but its relevance to diabetes remained unclear.

Recently Wong et al. [21] reported on a severely diabetic 3-day-old neonate in whom no immunocytochemically detectable insulin cells were found. With respect to the 40-week long gestation and birth weight of $2750 \mathrm{~g}$, this patient's intrauterine growth appeared to be at least marginally normal. This argues against an agenesis of beta cells, as fetal insulin is required for normal fetal growth. The insulin deficiency of this patient presumably developed late in the third trimester and therefore did not significantly affect the intrauterine growth. The authors therefore favoured the possibility of a rapid destruction of the fetal beta cells but evidence of an unequivocal damage to the islets, i.e. necrosis, inflammatory infiltration or fibrosis, was lacking. In our case, there was a significant intrauterine growth retardation which suggests the absence of insulin since the early stages of gestation.

The key feature of our patient's pancreas was the absence of immunoreactive insulin cells from the islets. The possibility that the immunostaining failed because of severe degranulation of the insulin cells was excluded by electron microscopic examination and in situ hybridiza- tion for insulin. At the ultrastructural level all endocrine cells were found to be granulated but to contain no secretory granules characterizing beta cells. In situ hybridization for insulin failed to reveal any binding signal over the pancreatic sections examined. We can therefore conclude that insulin cells were completely lacking in this pancreas.

There are several explanations for the congenital absence of beta cells from this neonate's pancreas. Firstly, as suggested by Wong et al. [21], the beta cells could have been selectively destroyed in utero by autoimmune mechanisms as seen in Type 1 diabetes. However, the mother did not have diabetes and the infant did not demonstrate ICA or IAA. In addition the child's HLA pattern was of the DQ genotype which is not associated with Type 1 diabetes [23].

Secondly, there may have been a Coxsackie virus infection because antibodies to Coxsackie viruses were measured in the infant's serum. However, this finding may be explained by the fact that the mother also had antibodies to Coxsackie viruses. Moreover, there were no signs of inflammation, neither in the endocrine nor the exocrine pancreas which could support a virus-related destruction of beta cells $[22,24]$. Infections with rubella and cytomegalovirus, which are also capable of damaging the beta cells, could be excluded as the mother was immunized against these viruses [25].

Thirdly, a genetic defect might be responsible for the congenital absence of pancreatic beta cells. In addition to diabetes, the child suffered from severe methylmalonic acidaemia, due to a defect of the methylmalonyl coenzyme A mutase apoenzyme [26]. Interestingly, the gene encoding the methylmalonyl CoA mutase (MUT) is mapped on chromosome 6p21 [27], thus close to the MHCgene cluster. These latter genes, particularly the HLA-DQ genotypes, are involved in autoimmune Type 1 diabetes susceptibility. However, as mentioned above, these specific HLA-DQ genotypes were not present in our patient. The association of our patient's diabetes with methylmalonyl acidaemia may therefore be merely coincidental.

In summary, we have studied a diabetic neonate with congenital absence of beta cells and associated methylmalonyl coenzyme A mutase apoenzyme defect. Clinically, the evolution of the diabetes was certainly influenced by the co-existing methylmalonic acidaemia, because metabolic acidosis and ketonuria, as well as hyperglycaemia, persisted despite aggressive treatment with bicarbonate and insulin.

Acknowledgements. The authors thank Prof. P.Fondu (Department of Haematology, Brugmann Hospital, Brussels, Belgium) for carrying out the bone marrow analysis; Dr. F. Schuit for the HLA-DQ genotyping (Belgium Diabetes Registry); Ms N. Buelens for technical assistance; Ms H.Lox and V. Olmanst for secretarial work (Department of Pathology, Brussels).

\section{References}

1. Dorchy H, Ooms H, Loeb H (1975) Permanent neonatal diabetes mellitus: a case report with plasma insulin studies. Eur J Pediatr (Z Kinderheilk) 118: 271-281

2. Dorchy H (1992) Permanent neonatal diabetes mellitus: lack of complications after a 20-year follow-up. Eur J Pediatr 151: 151 (Letter) 
3. Goumy P, Maroteaux P, Stanescu V, Stanescu R, Labbé G, Menut G (1980) Syndrome de transmission récessive autosomique associant un diabéte congénital et des désordres de la croissance des épiphyses. Arch Fr Pediatr 37: 323-328

4. Hoffman WH (1980) Prevalence of permanent congenital diabetes mellitus. Diabetologia 19: 487-488 (Letter)

5. Daugbjerg PS (1981) A case of permanent diabetes mellitus in a neonate. Dan Med Bull 28:216-218

6. Widness JA, Cowett RM, Zeller WP, Susa JB, Rubenstein AH, Schwartz R (1982) Permanent neonatal diabetes mellitus in an infant of an insulin-dependent mother. J Pediatr 100: 926-929

7. Hattewig G, Kjellman B, Fällström SP (1982) Congenital permanent diabetes mellitus and celiac disease. J Pediatr 101: 955-957

8. Knip M, Koivisto M, Käär ML, Puukka R, Kouvalainen K (1983) Pancreatic islet cell function and metabolic control in an infant with permanent neonatal diabetes. Acta Paediatr Scand 72:303 307

9. Barbotte E, Simonin G, Unal D, Coignet J (1983) Le diabéte néonatal. A propos de deux observations. Pédiatrie 41: 553-557

10. Cavallo L, Mautone A, La Forgia N, Fiore R, Zuppinger K (1987) Neonatal diabetes mellitus: evaluation of pancreatic $\beta$-cell function in two cases. Helv Paediatr Acta 42: 437-443

11. Ivarsson SA, Marner B, Lernmark $\AA$, Nilsson KO (1988) Nonislet pancreatic autoantibodies in sibship with permanent neonatal insulin-dependent diabetes mellitus. Diabetes 37: 347-350

12. Dourov N, Buyl-Strouvens ML (1969) Agénésie du pancréas. Arch Fr Pédiatr 26: 641-650

13. Sherwood WC, Chanck GW, Hill DE (1974) A new syndrome of familial pancreatic agenesis: the role of glucagon in somatic cell growth. Paediatr Res 8: 360 (Abstract)

14. Mehes K, Wamos K, Goda M (1976) Agenesis of pancreas and gall bladder in an infant of incest. Acta Paediatr Acad Sci Hung 17: 175-176

15. Wöckel W, Scheibner K (1977) Aplasie des Pankreas mit Diabetes mellitus, intrahepatische Gallengangsaplasie und weitere Missbildungen bei einem hypotrophen Neugeborenen. Zentralbl Allg Pathol 121: 186-194

16. Lemons JA, Ridenour R, Orsini EN (1979) Congenital absence of the pancreas and intrauterine growth retardation. Paediatrics 64:255-256

17. Howard CP, Go VLW, Infante AJ, Perrault J, Gerich JE, Haymond ML (1980) Long-term survival in a case of functional pancreatic agenesis. J Pediatr 97: 786-789
18. Bonus MB, Coutts JP (1982) Complete agenesis of the mid-gut: a case report. Austr N Z J Surg 52: 313-315

19. Moore RA (1936) Congenital aplasia of islands of Langerhans with diabetes mellitus. Am J Dis Child 52: 627-632

20. Dodge JA, Lawrence KM (1977) Congenital absence of islets of Langerhans. Arch Dis Child 52:411-413

21. Wong KC, Tse K, Chan JKL (1988) Congenital absence of insulin-secreting cells. Histopathology 12: 541-545

22. Klöppel G, Gepts W, Loeb H (1989) Anatomie pathologique du pancréas de l'enfant diabétique. In: Czernichow $\mathrm{P}$, Dorchy $\mathrm{H}$ (eds) Diabétologie pédiatrique. Doin, Paris, pp 85-101

23. Dorchy H, Vandewalle C, Decraene T, Nagy ZP, Schuit F, Gorus $\mathrm{F}$ (1992) Genetic and immunological markers in European Caucasians and Mograbin Caucasians with type 1 (insulin-dependent) diabetes residing in Belgium. Pediatr Adolesc Endocrinol (in press)

24. Klöppel G, Gepts W, In't Veld PA (1992) Morphology of the pancreas in normal and diabetic states. In: Alberti KGMM, DeFronzo RA, Zimmet P (eds) International textbook of diabetes mellitus. John Wiley, Chichester, pp 223-259

25. Drash AL (1989) Virus et diabète de type 1. In: Czernichow P, Dorchy H (eds) Diabétologie pédiatrique. Doin, Paris, pp 51-68

26. Rosenberg LE, Fenton NA (1989) Disorders of propionate and methylmalonate metabolism. In: Seriver CR, Beaudet AL, Sly WS, Valle D (eds) The metabolic basis of inherited disease. Mc Graw-Hill, New York, pp 821-844

27. Ledley FD, Lumetta MR, Zoghbi HY, Van Tuinen P, Ledbetter SA, Ledbetter DH (1988) Mapping of human methylmalonyl CoA mutase (MUT) locus of chromosome 6 . Am J Hum Genet 42: 839-846

Received: 10 August 1992

and in revised form: 8 December 1992

Professor G. Klöppel

Department of Experimental Pathology

Free University of Brussels

Campus Jette

Laarbeeklaan 103

B-1090 Brussels

Belgium 